\title{
Yield and sensory properties of cheese made with milk from Holstein or Montbéliarde cows milked twice or once daily
}

\author{
B. Martin,${ }^{* 1}$ D. Pomiès, ${ }^{*}$ P. Pradel, $\dagger$ I. Verdier-Metz,‡ and B. Rémond§ \\ ${ }^{*}$ INRA, UR1213 Herbivores, F-63122 Saint-Genès-Champanelle, France \\ †INRA, UE1296 des Monts d'Auvergne, F-63210 Orcival, France \\ fINRA, UR545 Fromagères, Route de Salers, F-15000 Aurillac, France \\ §ENITAC, Unité Elevage et Productions des Ruminants, INRA, USC2005, F-63370 Lempdes, France
}

\begin{abstract}
The aim of this study was to evaluate the milk properties and the yield and sensory properties of Cantal cheese made with milk from Holstein or Montbéliarde cows milked once or twice daily. Sixty-four grazing cows [32 Holstein $(\mathrm{H})$ and 32 Montbéliarde $(\mathrm{M})$ cows] in the declining phase of lactation (157 d in milk) were allocated to 1 of 2 equivalent groups milked once daily (ODM) or twice daily (TDM) for $7 \mathrm{wk}$. The full-fat raw milk collected during $24 \mathrm{~h}$ from the 4 groups of cows (M-TDM, M-ODM, H-TDM, and H-ODM) was pooled and processed into Cantal cheese 4 times during the last 4 wk of the experimental period. In all, 16 cheeses were made $(2$ milking frequencies $\times 2$ breeds $\times 4$ replicates) and analyzed after a ripening period of 15 and 28 wk. The results showed that for both breeds, the pooled milk content of fat, whey protein, casein, total protein, and phosphorus as well as rennet clotting time and curd firming time were significantly higher with ODM cows, whereas the casein-to-total protein ratio was lower, and lactose, urea, calcium, and free fatty acids contents of milk remained unchanged. The acidification and draining kinetics of the cheese as well as cheese yields and the chemical and rheological properties of the ripened cheese were not significantly modified by milking frequency. For both breeds, the cheeses derived from ODM cows had a slightly yellower coloration but the other sensory attributes, except for pepper odor, were not significantly affected by milking frequency, thereby demonstrating that ODM does not have an adverse effect on the sensory properties of Cantal cheese. Compared with that of Holstein cows, milk from Montbéliarde cows resulted in a higher cheese yield $(+1.250 \mathrm{~kg} / 100 \mathrm{~kg}$ of milk) and ripened cheeses with lower $\mathrm{pH}$, dry matter, calcium, sodium chloride, and water-soluble nitrogen concentrations. These cheeses
\end{abstract}

Received November 20, 2008.

Accepted June 2, 2009.

${ }^{1}$ Corresponding author: bmartin@clermont.inra.fr had also a less firm and more elastic texture, a more acidic taste, and a yogurt/whey aroma.

Key words: once-daily milking, milk composition, cheese yield, cheese sensory quality

\section{INTRODUCTION}

The implementation of once-daily milking (ODM) could be an interesting solution for reducing producers' routine labor at least temporarily and thus satisfy the growing aspiration of dairy producers toward fewer constraints and extended leisure time. Even if ODM inevitably results in a noticeable decrease in milk yield ( -20 to $-50 \%$ according to animal lactation stage, parity, and breed; Rémond and Pomiès, 2005), this practice is of great interest for some farmers who can comfortably endure (at least for short periods) the milk losses. Once-daily milking also results in changes in mammary permeability leading to changes in both major and minor milk constituents through increased influx of serum proteins and ions and increased efflux of lactose and potassium (Davis et al., 1999). Once-daily milking increases milk fat and protein content and decreases lactose content by an average of $+2.8,+1.5$, and -1.5 $\mathrm{g} / \mathrm{L}$, respectively (Rémond and Pomiès, 2005). The increase in protein content is due to both casein and whey protein, but the relatively high increase in whey protein content is responsible for the reduced caseinto-protein ratio generally reported (Claesson et al., 1959; Auldist and Prosser, 1998; O'Brien et al., 2002; Rémond and Pomiès, 2005). Milk SCC is not affected (Stelwagen et al., 1994; Lacy-Hulbert et al., 1999) or is moderately increased (Kelly et al., 1998; O'Brien et al., 2002; Rémond and Pomiès, 2005). Once-daily milking also tends to increase milk protease activity (Stelwagen et al., 1994; Kelly et al., 1998; Lacy-Hulbert et al., 1999) but decreases lipase activity (Rémond and Pomiès, 2005; Pomiès et al., 2007). Last, again depending on the experiments, the coagulation properties of milks are either unaffected by ODM (O'Brien et al., 2002) or are improved (Pomiès et al., 2007). 
The large influence of ODM on milk characteristics means that the cheese-making ability of the milk and the resulting characteristics of cheese from ODM cows could also be modified. The influence of 3-times-daily milking compared with twice-daily milking (TDM) has been tested on Cheddar cheese characteristics (Sapru et al., 1997), but to our knowledge, ODM has never been tested on cheese characteristics in a specifically designed trial. This study was designed to 1) evaluate yield and sensory properties of Cantal cheese made with milk from cows milked once or twice daily and 2) study the effect of breed (Holstein vs. Montbéliarde) and its interaction with milking frequency on cheese yield and sensory properties. Indeed, the cheese derived from Holstein and Montbéliarde breeds has been compared in some previous studies reviewed by Coulon et al. (2004), but contradictory results were reported.

\section{MATERIALS AND METHODS}

\section{Experimental Design and Animal Management}

During a 2-wk pre-experimental period, 32 Holstein $(\mathbf{H})$ and 32 Montbéliarde (M) cows were fed a permanent mountain diversified pasture and concentrate. The individual milk yield, milk protein and fat contents, and SCC recorded during this period, as well as calving date, parity, BW, and parity were used to allocate the cows in 2 equivalent groups within each breed. The allelic frequency of the $\kappa$-casein $\mathrm{B}$ variant was equivalent in both groups of each breed: 28 and $25 \%$ for Holstein cow groups and 48 and 50\% for Montbéliarde cow groups. Milking frequency treatments TDM and ODM began on June 4 and were applied to 1 of the 2 groups per breed during 7 consecutive weeks. The TDM treatment consisted of a morning and an evening milking between 0630 and $0800 \mathrm{~h}$ and 1600 and $1730 \mathrm{~h}$, respectively, and ODM consisted of the morning milking only. Concentrate given to cows after the morning milking during the pre-experimental period remained unchanged during the entire experimental period. The ODM and TDM cows separately grazed 2 distinct paddocks alternated daily. The 2 paddocks were distant enough so that the ODM cows could not see or hear TDM cows going to the milking machine for the evening milking.

\section{Cheesemaking}

During the first 3 wk of the experimental period, cows were adapted to the treatments. During the remaining $4 \mathrm{wk}$ of the experimental period, Cantal cheese, a French Protected Denomination of Origin (PDO) hard cheese, was made under controlled conditions using the raw milk obtained from the 16 cows of one of the following groups: TDM-H, TDM-M, ODM-H, and ODM-M. The day before each cheesemaking, the milk from ODM cows was stored for $24 \mathrm{~h}$ at $4^{\circ} \mathrm{C}$. The morning milk from TDM was cooled at $4^{\circ} \mathrm{C}$, pooled with the evening milk, and stored at $4^{\circ} \mathrm{C}$ overnight for the cheesemaking. Small Cantal cheeses $(10 \mathrm{~kg}$ instead of $40 \mathrm{~kg}$ ) were manufactured from $110 \mathrm{~L}$ of TDM or ODM milk, $2 \mathrm{~d} /$ wk, with one day being devoted to each breed. Each day, the TDM and ODM full-fat raw milks were manufactured in parallel in 2 vats. In each vat, the milk was heated to $33^{\circ} \mathrm{C}$ and inoculated with $0.2 \mathrm{~g}$ of a lyophilized, mesophilic starter culture (Flora Danica Direct, Chr. Hansen, Arpajon, France) reconstituted in sterile skimmed milk $(100 \mathrm{~g} / \mathrm{L})$, with a ripening starter (2 mL of Monilev and $1.5 \mathrm{~mL}$ of Penbac, Laboratoire Interprofessionnel de Production, Aurillac, France) and $0.33 \mathrm{~g} / \mathrm{kg}$ of a rennet (Beaugel 500, Villefranche sur Soane, France) containing $520 \mathrm{mg}$ of active chymosin per liter. Forty-five minutes later, the curd was cut for $5 \mathrm{~min}$ to produce pellets 5 to $6 \mathrm{~mm}$ in diameter. The curd-whey mixture was then blended for $12 \mathrm{~min}$ and left to stand for $7 \mathrm{~min}$. After draining the whey, the curd was placed in a pressing tray where it was pressed, cut in 15-cm cubes, and turned 12 times in approximately $3 \mathrm{~h}$ to reach 50\% DM. After pressing, the curd cubes were left to drain for $24 \mathrm{~h}$ at $20^{\circ} \mathrm{C}$ and were pounded into grains $20 \mathrm{~mm}$ in diameter. The mixture was salted with $20 \mathrm{~g} / \mathrm{kg}$ dry salt and left to stand for $6 \mathrm{~h}$ at $20^{\circ} \mathrm{C}$ before one cheese per vat was formed in a cloth mold and pressed for $24 \mathrm{~h}$ at $13^{\circ} \mathrm{C}$. Overall, 16 vats were processed during $8 \mathrm{~d}$ and produced 16 Cantal cheeses $(2$ breeds $\times 2$ milking frequencies $\times$ 4 replicates). Fresh cheeses were placed in a ripening cellar for 15 wk at $10^{\circ} \mathrm{C}$ and $95 \%$ minimum relative humidity. Cheeses were then sampled for analyses and the part left (about $5 \mathrm{~kg}$ /cheese) was replaced into the cellar for an additional 13 wk. The cheese aged for 28 wk was sampled for analyses.

\section{Analysis}

Milk. Milk sample from the pooled milk used for cheesemaking was collected in each vat just before the rennet and starter addition for gross and detailed composition analyses and clotting ability measurement. Fat and protein contents were measured by infrared spectrophotometry (MilkoScan 4000, Foss System, Hillerød, Denmark) and, in the same samples, somatic cells were automatically counted (Fossomatic 5000, Foss System). Detailed composition analyses consisted in the determination of urea content (dimethyl amino benzaldehyde), calcium and phosphorus contents (spectrometry), and total, soluble, and nonprotein $\mathrm{N}$ measured according to Rowland (1938). Casein N was calculated as the 
difference between total and soluble $\mathrm{N}$, total protein as the difference between total and nonprotein $\mathrm{N}$, and casein:protein ratio was expressed as casein/total protein $\times 100$. Free fatty acid analyses (Jellema, 1991) were achieved on fresh unfrozen samples. Bulk milk coagulation properties (rennet clotting time, curd firming time required to achieve $20 \mathrm{~mm}$ firmness, curd firmness after $30 \mathrm{~min}$ and after a firming time equal to clotting time) were also evaluated at milk natural $\mathrm{pH}$ and standardized $\mathrm{pH}$ (6.60), using a Formagraph apparatus according to the method proposed by McMahon and Brown (1982) and as described in Verdier-Metz et al. (2000). Milk pH was measured at $20^{\circ} \mathrm{C}$ using an Ingold needle (Ingold France, Paris, France).

Cheese. The $\mathrm{pH}$ was measured at $20^{\circ} \mathrm{C}$ by introducing an Ingold electrode (Ingold France) into some ground cheese. Dry matter content was determined by desiccation at $103^{\circ} \mathrm{C}$ for $24 \mathrm{~h}$, and fat content was measured by butyrometric method according to the IDF standards. Total nitrogen, water-soluble nitrogen, and phosphotungstic acid soluble nitrogen were measured using the methods described by Ardö (1999). The measurements of the curd color of cheeses were detailed in Verdier-Metz et al. (2000). The rheological method used was uniaxial compression at constant displacement rate. A Lloyd testing machine (Ametek S.A.S, Lloyd Instruments and Chatillon, Elancourt, France) equipped with parallel plates and a 500-N load cell was used. The displacement rate was $50 \mathrm{~mm} / \mathrm{min}$. Ten cylindrical specimens were tested for each cheese sample. The cylinders (20 mm diameter) were cut to a height of $20 \mathrm{~mm}$. Test pieces were stored in a small airtight box (to avoid desiccation) for $1 \mathrm{~h}$ to permit relaxation before testing at $20^{\circ} \mathrm{C}$. Force and displacement data were recorded. The force and height variation data were computed as stress/strain curves. The cheese sensory properties were assessed by a panel of 12 expert assessors who perform routine sensory analyses of Cantal cheese. The assessors were selected $3 \mathrm{yr}$ ago for their ability to detect and recognize basic tastes and odors. Then, they were trained to improve their skills with both diluted pure compounds and Cantal cheese. This work permitted us to define a specific list of sensory attributes for Cantal cheeses. The performance of the panel was assessed every 3 mo during specific training sessions using odor and flavor recognition tests, ranking tests, and descriptive ability tests. Before the experimental sessions, the panelists had 2 additional training sessions with cheeses made in this trial to define a specific list of attributes for this experiment. During the experimental sessions, panelists scored between 0 and 7 the intensity of 27 attributes (2 for texture, 10 for odor, 11 for aroma, 4 for taste). During one session, the 4 cheeses made the same week were coded with a 3 -digit random numbers and presented at $20^{\circ} \mathrm{C}$ to the panelists in varying order using a monadic sequential method. In total, 4 sessions were necessary to analyze the cheeses ripened for 15 wk and 4 additional sessions were necessary to analyze the cheeses ripened for 28 wk. Cheese yield was calculated as cheese weight $/ 110 \times 100$, and the cheese yield expressed in DM was calculated as cheese yield $\times$ cheese DM/100. Cheeses were weighed at molding, at placement in the cellar, and at the end of ripening.

\section{Statistical Analyses}

One milk and cheese derived from the H-ODM group were removed from the data set because the milk SCC was 894,000 cell $/ \mathrm{mL}$. Data were processed using SAS software (version 8.6, SAS Institute Inc., Cary, NC). In a first step, data on the milk and on the $\mathrm{pH}, \mathrm{DM}$, and yield observed at different key cheese-making steps were processed by ANOVA (GLM procedure), factoring in milking frequency, breed, and their interaction (milking $\times$ breed). Data on the cheeses ripened for 15 and 28 wh were processed using the MIXED procedure of the SAS software: milking frequency, breed, ripening time (age), and their interactions (milking $\times$ breed, milking $\times$ age, breed $\times$ age, milking $\times$ breed $\times$ age) were the fixed factors, repetition was the random factor, and ripening time was the repeated factor. The assessor was also introduced into the model for sensory data.

\section{RESULTS AND DISCUSSION}

\section{Milk Characteristics}

Milking Frequency. The increase in milk fat and protein content in response to ODM $(+2.7$ and +2.3 $\mathrm{g} / \mathrm{L}$, respectively; Table 1) is in full agreement with the literature (Davis et al., 1999; O'Brien et al., 2002; Rémond and Pomiès, 2005) and was similar in the 2 breeds, as observed in Pomiès et al., (2007). For both $\mathrm{H}$ and $\mathrm{M}$ breeds, total $\mathrm{N}$ and casein were higher, but the casein:protein ratio was $2 \%$ lower in ODM milks because of the simultaneous higher increase in the soluble protein concentration. Similar previously reported results (Rémond and Pomiès, 2005) were explained by possible leakage at the tight junctions within the mammary gland (Stelwagen et al., 1997) that could be responsible for an increased influx of serum proteins into milk (Davis et al., 1999). In agreement with previous reports (Lacy-Hulbert et al., 1999; Pomiès et al., 2007), for both breeds, ODM milks were also richer in $\mathrm{P}(+0.08 \mathrm{~g} / \mathrm{L})$. In contrast, milking frequency had no significant effect on milk lactose, $\mathrm{Ca}$, and urea contents. The slightly reduced level of FFA in ODM milks confirms the tendency already reported by Pomiès et 
Table 1. Composition and coagulation properties of bulk milks from Holstein and Montbeliarde cows milked once daily (ODM) or twice daily $(\mathrm{TDM})^{1}$

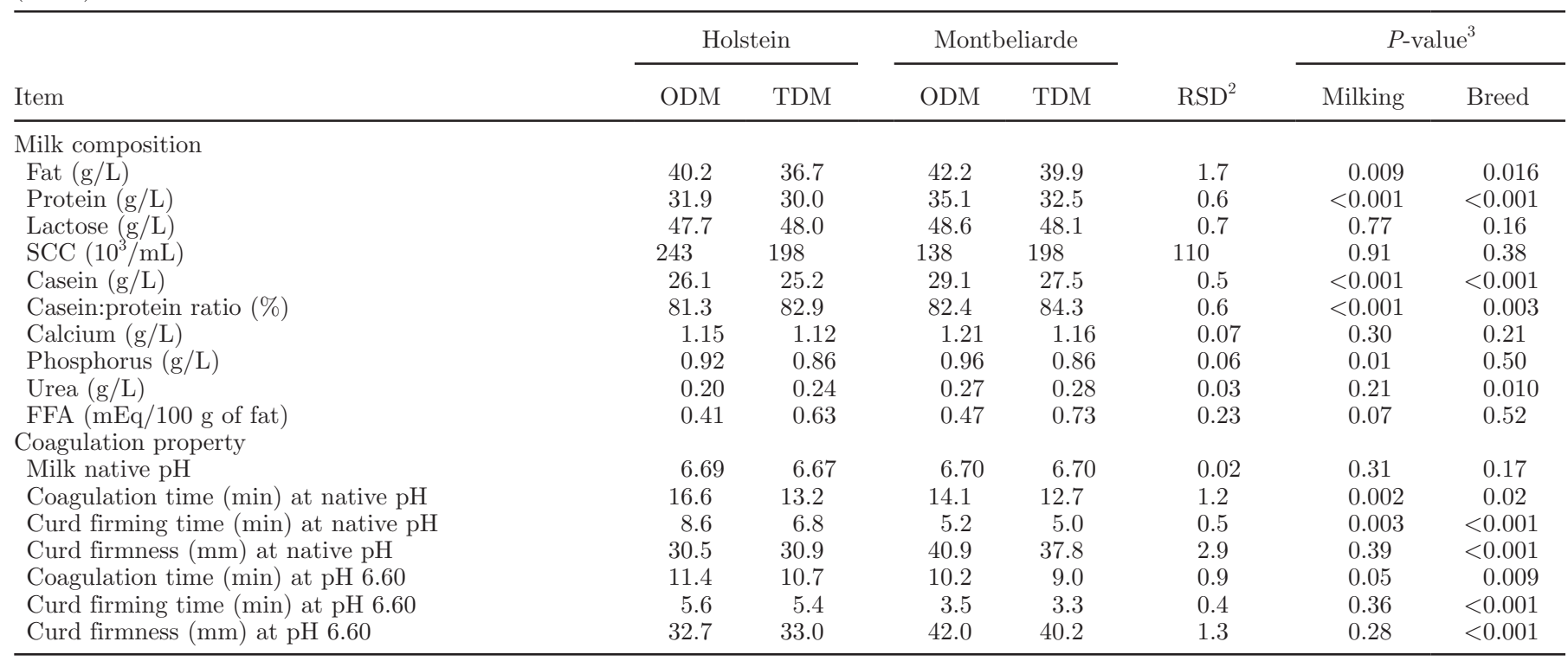

${ }^{1}$ Values are the means of 4 measurements.

${ }^{2} \mathrm{RSD}=$ residual standard deviation.

${ }^{3}$ All $P$-values for the milking $\times$ breed interactions are $>0.10$, except for curd firming rate measured at natural $\mathrm{pH}(P=0.01)$.

al. (2004, 2007), who ascribed this FFA reduction to a decreased lipoprotein lipase activity of ODM milks because of the increase in milking interval (Chilliard and Lamberet, 1984). Nevertheless, the decrease in FFA observed in our trial was smaller and nonsignificant. The lack of increase in SCC due to ODM that we observed and that is sometimes reported (Kelly et al., 1998) seems to be a constant feature when animals have a low initial SCC (O'Brien et al., 2002; Pomiès et al., 2007) as was the case in our trial.

At native $\mathrm{pH}$, ODM significantly increased coagulation time and curd firming rate, which seems to be independent of a concomitant increase in milk $\mathrm{pH}$, even if this effect is largely reduced when $\mathrm{pH}$ is adjusted to the native 6.60. As already reported by Pomiès et al. (2007), it is more probably a consequence of the increase in casein levels that reduces the enzyme/substrate ratio, with the result that chymosin takes more time to achieve the $70 \%$ cleavage of $\kappa$-caseins required for milk flocculation. However, these differences disappeared once milk $\mathrm{pH}$ was standardized to 6.60 . In contrast, as already observed by O'Brien et al. (2002), ODM had no effect on curd firmness, which is closely related to milk casein content (Macheboeuf et al., 1993; Martin and Coulon, 1995) that increased only moderately.

Breed. Compared with Holstein milk, the milks derived from Montbéliarde cows were richer in fat, protein, caseins, and urea as frequently observed (Macheboeuf et al., 1993; Verdier-Metz et al., 1998; Pomiès et al., 2007). Montbéliarde milks also had a higher casein:protein ra- tiothat may be linked to casein genetic polymorphism of the $\beta$-lactoglobulin and $\kappa$-casein (Coulon et al., 1998) as the respective allele frequency of $\mathrm{B}$ variants was 25 and $23 \%$ higher in $\mathrm{M}$ milks. The $\mathrm{M}$ milks had a shorter coagulation time and curd firming rate, and gave rise to a firmer curd, both at native or standardized $\mathrm{pH}$. As previously reported (Macheboeuf et al., 1993), the better coagulation properties of $\mathrm{M}$ milks can be largely ascribed to the higher casein content of $\mathrm{M}$ milk and the higher frequency of $\kappa$-casein $\mathrm{B}$ variant in $\mathrm{M}$ milk. With the exception of curd firming rate at native $\mathrm{pH}$, there were no other significant interactions between breed and milking frequency.

\section{Cheese Yield, pH, and Acidification Kinetics}

Milking Frequency. During cheese-making, there were no significant between-treatment differences in acidification and draining kinetics or cheese yields (Figure 1). After 15 wk of ripening, compared with TDM, ODM milk produced on average $140 \mathrm{~g}(+1.6 \%)$ and 190 $\mathrm{g}(+1.9 \%)$ more ripened cheese per $100 \mathrm{~kg}$ of milk from $\mathrm{H}$ and $\mathrm{M}$ cows, respectively. These numerical differences were nonsignificant regardless of whether cheese yields were fresh or expressed in DM and surprisingly low considering the ODM-induced increases in fat and protein contents (Verdier-Metz et al., 2001). This may partly be explained by the lower casein:protein ratio of ODM milks and the similarities in coagulation properties between ODM and TDM milks that could have 

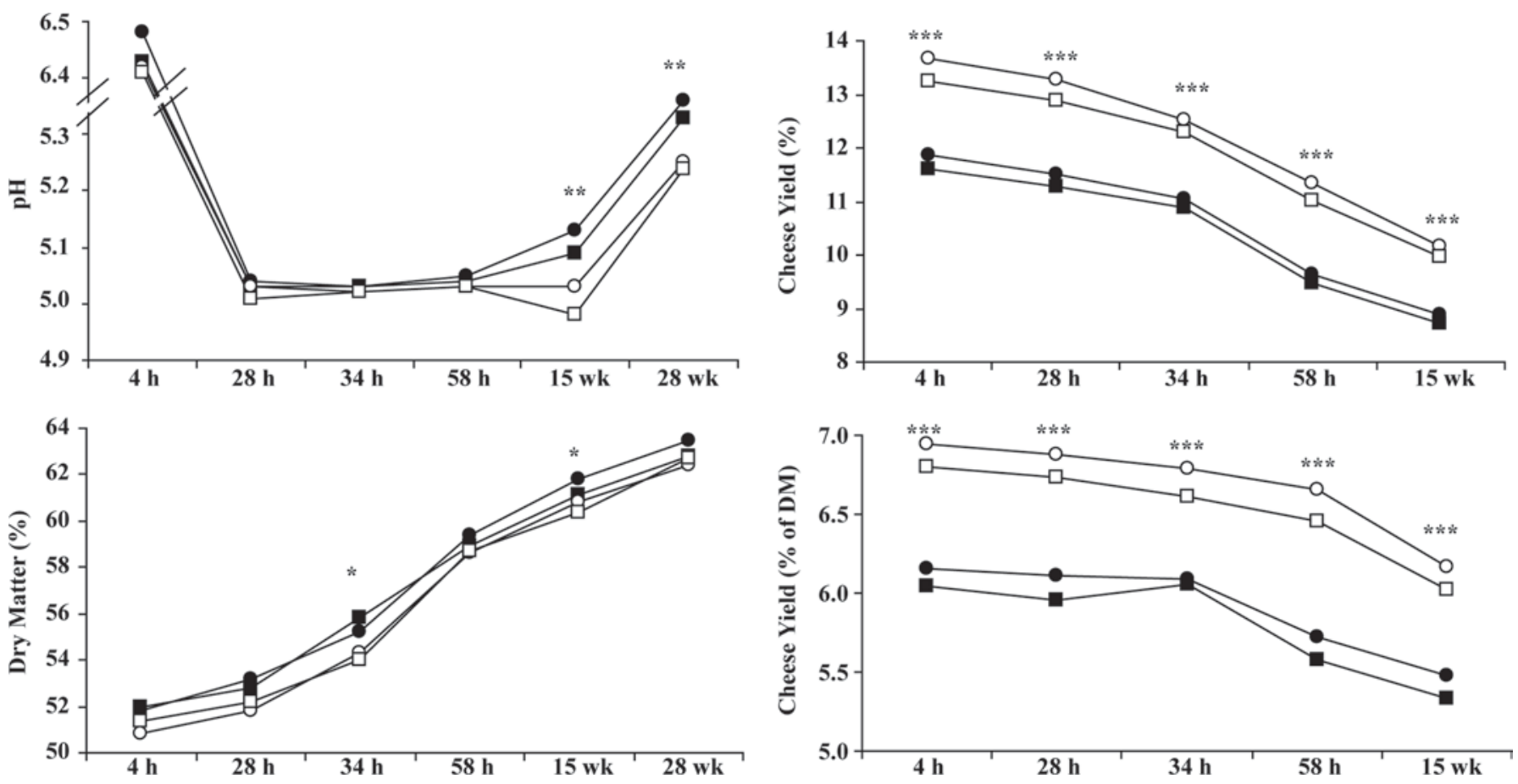

Figure 1. Cheese pH, dry matter, and yield (expressed in $\mathrm{kg}$ of cheese/100 kg of milk and in $\mathrm{kg} \mathrm{DM}$ of cheese/100 kg of milk) for Holstein $(\mathrm{H})$ and Montbeliarde (M) cows milked once daily (ODM) or twice daily (TDM) measured at $4 \mathrm{~h}$ (pressed curd), $28 \mathrm{~h}$ (pounded curd), $34 \mathrm{~h}$ (molding), $58 \mathrm{~h}$ (placing in cellar), $15 \mathrm{wk}$ and 28 wk after the rennet addition. $\mathbf{\square}=\mathrm{H}$-TDM; $\square=\mathrm{M}-\mathrm{TDM} ; \boldsymbol{\bullet}=\mathrm{H}-\mathrm{ODM} ; \bigcirc=\mathrm{M}-\mathrm{ODM} ; *{ }^{*} *$,

*** $P$-values for the breed effect are $<0.05,0.01$, and 0.001 , respectively; $P$-values for milking frequency and the interaction breed $\times$ milking are $>0.05$.

reduced the yield gain predicted based on their compositional differences.

Breed. In contrast to milking frequency, breed has a much stronger effect: $100 \mathrm{~kg}$ of M milk produced 1.265 $\mathrm{kg}(+12.6 \%)$ more cheese at $15 \mathrm{wk}$ of ripening than $100 \mathrm{~kg}$ of $\mathrm{H}$ milk $(P<0.0001)$. This is linked to the higher casein and fat content of $\mathrm{M}$ milks. Nevertheless, considering the model proposed by Verdier-Metz et al. (2001) for another pressed cheese (Saint-Nectaire) made in the same cheese plant, the DM yield gain for M cheese is $50 \%$ higher than the DM yield gain expected considering the breed-related differences in milk fat and protein contents. This higher yield gain is almost certainly linked to the better coagulation properties of $\mathrm{M}$ milks and their higher allele frequency of $\kappa$-casein $\mathrm{B}$ variant.

Nevertheless, the effects of ODM and breed on cheese yield remains to be confirmed, as a precise evaluation of cheese yield requires a greater number of replicates than was employed in this trial $(\mathrm{n}=4)$.

\section{Cheese Chemical and Sensory Characteristics}

Ripening. The ripened cheese characteristics first varied according to the well-known effect of ripen- ing time (Fox et al., 1999). During aging, there were significant increases in cheese $\mathrm{pH}, \mathrm{DM}$, sodium chloride, and proteolysis indicators, whereas the calcium content of the cheese decreased significantly (Table 2). In parallel, cheese texture became less elastic and the microstructure more developed, while the taste became more persistent and salty (Table 3 ). The effect of cheese age on salty taste was more marked for $\mathrm{M}$ cheese than for $\mathrm{H}$ cheese. During aging, aroma intensity also increased, together with the stronger odors and aromas such as fermented cream odor and aroma, stable odor and aroma, and fermented grass, egg, and pepper aromas, whereas the softer odors and aromas (butter odor, yogurt and vanilla aromas) decreased. Texture evolution and time-related fading of mild odor and aroma attributes to the benefit of stronger features were consistent with the time-related increases in $\mathrm{pH}, \mathrm{DM}$, chlorides, and proteolysis estimated by the proportion of water-soluble nitrogen (Grappin et al., 1985). These changes are linked to sugar, protein, and fat catabolism, all of which become more important as ripening time increases.

Breed. Even if the experimental design was not ideally suited to test the effect of cow breed on the properties of the cheese produced (the milks from the 
Table 2. Chemical and rheological characteristics of Cantal cheeses ripened for 15 and 28 wk and made with milks from Holstein or Montbeliarde cows milked twice daily (TDM) or once daily $(\mathrm{ODM})^{1}$

\begin{tabular}{|c|c|c|c|c|c|c|c|c|c|c|c|}
\hline Characteristic & \multicolumn{4}{|c|}{15 wk } & \multicolumn{4}{|c|}{28 wk } & & & \\
\hline $\mathrm{pH}$ & 5.13 & 5.09 & 5.03 & 4.98 & 5.36 & 5.33 & 5.25 & 5.24 & 0.192 & 0.001 & $<0.0001$ \\
\hline DM (\%) & 61.8 & 61.1 & 60.8 & 60.4 & 63.5 & 62.8 & 62.4 & 62.7 & 0.132 & 0.007 & $<0.0001$ \\
\hline Fat in DM $(\%)$ & 51.8 & 51.4 & 52.1 & 52.4 & 52.0 & 51.4 & 52.3 & 52.4 & 0.632 & 0.032 & 0.883 \\
\hline $\mathrm{WSN}^{3}(\%$ of total $\mathrm{N})$ & 18.4 & 17.5 & 17.2 & 17.4 & 24.1 & 23.1 & 22.5 & 22.4 & 0.067 & 0.003 & $<0.0001$ \\
\hline $\operatorname{PTSN}^{4}(\%$ of total N$)$ & 5.8 & 8.2 & 5.6 & 6.5 & 9.6 & 9.6 & 10.0 & 9.1 & 0.169 & 0.253 & $<0.0001$ \\
\hline \multicolumn{12}{|l|}{ Cheese color ${ }^{5}$} \\
\hline L (lightness) & 80.4 & 80.7 & 82.0 & 81.5 & & & & & 0.951 & 0.228 & \\
\hline a (red-green) & 1.9 & 1.6 & 1.8 & 1.7 & & & & & 0.091 & 0.696 & \\
\hline b (yellow-blue) & 23.1 & 21.7 & 22.5 & 21.7 & & & & & 0.027 & 0.482 & \\
\hline \multicolumn{12}{|c|}{ Instrument-based texture measurements ${ }^{5}\left(\mathrm{~N} / \mathrm{cm}^{2}\right)$} \\
\hline
\end{tabular}

${ }^{1}$ Values are the means of 4 measurements.

${ }^{2}$ All the $P$-values for the interactions milking $\times$ breed, milking $\times$ age, breed $\times$ age, and milking $\times$ breed $\times$ age are $>0.05$, except milking $\times$ age for PTSN (\% of total N) where $P=0.027$.

${ }^{3}$ Water-soluble nitrogen.

${ }^{4}$ Phosphotungstic acid soluble nitrogen.

${ }^{5}$ Cheese color and texture measurements were not evaluated after the wk 28 ripening time point.

2 breeds were not manufactured on the same day), some interesting results can be highlighted. Cheese made from $\mathrm{M}$ milk had significantly $(P<0.05)$ lower $\mathrm{pH}, \mathrm{DM}$, calcium, and sodium chloride contents and water-soluble $\mathrm{N}$ fraction, and a slightly higher fat in DM (Table 2). The slower primary proteolysis and the lower calcium content of the $\mathrm{M}$ cheese are consistent with both the rheological and texture breed-related differences observed. Indeed, the M cheese tended to be firmer, at least when considering the numerically higher force necessary to create a small deformation (15\%), and they were characterized by a less elastic texture and a more marked microstructure (Table 3 ). This result is different from the described previously effect of $\mathrm{H}$ and M breeds on Saint-Nectaire cheese made with partially skimmed milks (Verdier et al., 1995; Verdier-Metz et al., 1998) but is consistent with other results obtained with full-fat raw milk (Martin et al., 2000), as was the case in our study. Nevertheless, Martin et al. (2000) ascribed the firmer texture of $\mathrm{M}$ cheese to fat in DM, which was lower in $\mathrm{M}$ cheese because of the lower fat-to-protein ratio in $\mathrm{M}$ milks. Our study showed, on the contrary, a slightly higher fat in DM in $\mathrm{M}$ cheese. The texture differences we observed are more probably linked to the higher primary proteolysis of $\mathrm{H}$ cheese (higher $\mathrm{pH}$ and water-soluble N). Verdier-Metz et al. (1998) also reported a higher $\mathrm{pH}$ of $\mathrm{H}$ cheese than $\mathrm{M}$ cheese, but they did not measure $\mathrm{N}$ fractions and the origin of the differences remained unexplained. The breed-related differences we observed for cheese proteolysis could be linked to a possible higher protease activity of $\mathrm{H}$ milk (Bastian and Brown, 1996), which is known to have a high plasmin activity compared with Jersey milk (Richardson, 1983; Schaar, 1985), but to our knowledge, the plasmin activity of milks from $\mathrm{H}$ and $\mathrm{M}$ cows has never been compared. The higher calcium content of $\mathrm{H}$ cheese could also explain in part their more elastic texture. Nevertheless, the breed-related difference in cheese calcium content is difficult to explain. It is governed mainly by the kinetics of acidification (Lucey and Fox, 1993), which was very similar between the 2 breeds: the difference in $\mathrm{pH}$ noted during cheese-making between $\mathrm{H}$ and $\mathrm{M}$ cheese never exceeded 0.03 (Figure 1).

The cheeses derived from $\mathrm{M}$ cows were also characterized by a stronger yogurt/whey aroma and a more acidic taste that are consistent with their low $\mathrm{pH}$ and proteolysis. The $\mathrm{M}$ cheese also tended to have less vanilla aroma and less rancid odor when they were ripened for $28 \mathrm{wk}(P<0.05$ on the interaction breed $\times$ age for rancid odor).

Milking Frequency. Compared with the effects of ripening time and breed, the effect of milking frequency on the cheese chemical and sensory properties was extremely low: of all 27 attributes used to describe 
Table 3. Sensory characteristics of Cantal cheeses ripened for 15 and 28 wk and made with milks from Holstein or Montbeliarde cows milked twice daily (TDM) or once daily (ODM)

\begin{tabular}{|c|c|c|c|c|c|c|c|c|c|c|c|c|}
\hline Characteristic & \multicolumn{4}{|c|}{$15 \mathrm{wk}$} & \multicolumn{4}{|c|}{$28 \mathrm{wk}$} & & & & \\
\hline \multicolumn{13}{|l|}{ Odor } \\
\hline Intensity & 4.0 & 4.2 & 4.4 & 4.1 & 4.3 & 4.2 & 4.4 & 4.2 & 0.364 & 0.224 & 0.108 & 0.423 \\
\hline Butter & 1.8 & 1.8 & 1.9 & 2.1 & 1.8 & 1.2 & 1.7 & 1.6 & 0.419 & 0.254 & 0.027 & 0.958 \\
\hline Grass & 0.9 & 0.6 & 0.7 & 0.5 & 0.7 & 0.5 & 0.4 & 0.9 & 0.662 & 0.625 & 0.605 & 0.433 \\
\hline Vanilla & 0.9 & 0.8 & 1.0 & 0.8 & 0.9 & 0.6 & 0.9 & 0.8 & 0.257 & 0.617 & 0.624 & 0.764 \\
\hline Stable & 1.0 & 1.0 & 1.1 & 0.7 & 1.2 & 1.8 & 1.5 & 1.5 & 0.758 & 0.751 & 0.001 & 0.825 \\
\hline Egg/sulfur & 0.8 & 0.8 & 1.0 & 1.0 & 1.0 & 1.1 & 1.2 & 1.1 & 0.973 & 0.270 & 0.176 & 0.632 \\
\hline Rancid & 0.3 & 0.5 & 0.4 & 0.6 & 1.0 & 0.8 & 0.5 & 0.3 & 0.990 & 0.099 & 0.072 & 0.018 \\
\hline Pepper & 0.2 & 0.4 & 0.5 & 0.6 & 0.2 & 0.7 & 0.3 & 0.5 & 0.020 & 0.279 & 0.831 & 0.253 \\
\hline \multicolumn{13}{|l|}{ Aroma } \\
\hline Fermented grass & 0.6 & 0.9 & 1.1 & 0.8 & 1.7 & 1.8 & 1.6 & 1.9 & 0.546 & 0.636 & $<0.0001$ & 0.563 \\
\hline Vanilla & 0.2 & 0.3 & 0.1 & 0.1 & 0.1 & 0.1 & 0.0 & 0.1 & 0.784 & 0.061 & 0.083 & 0.406 \\
\hline Stable & 0.6 & 0.6 & 0.9 & 0.4 & 1.4 & 1.8 & 1.2 & 1.2 & 0.762 & 0.299 & $<0.0001$ & 0.131 \\
\hline Egg/sulfur & 0.4 & 0.5 & 0.9 & 0.4 & 0.9 & 1.3 & 1.2 & 1.1 & 0.838 & 0.252 & $<0.0001$ & 0.486 \\
\hline Rancid & 1.3 & 1.5 & 1.3 & 1.4 & 1.3 & 1.7 & 1.1 & 1.6 & 0.117 & 0.525 & 0.840 & 0.702 \\
\hline Pepper & 0.5 & 0.5 & 0.7 & 0.7 & 1.0 & 0.8 & 0.9 & 0.7 & 0.551 & 0.689 & 0.041 & 0.230 \\
\hline \multicolumn{13}{|l|}{ Taste } \\
\hline Salted & 3.2 & 2.9 & 2.9 & 2.7 & 3.4 & 3.6 & 3.8 & 3.9 & 0.692 & 0.869 & $<0.0001$ & 0.021 \\
\hline Acid & 2.8 & 2.9 & 3.4 & 3.5 & 2.9 & 2.9 & 3.1 & 3.0 & 0.987 & 0.016 & 0.279 & 0.157 \\
\hline Bitter & 1.1 & 1.2 & 1.4 & 1.2 & 1.4 & 1.6 & 1.6 & 1.4 & 0.935 & 0.545 & 0.089 & 0.671 \\
\hline Persistent & 4.4 & 4.5 & 4.7 & 4.5 & 5.0 & 4.9 & 4.9 & 4.9 & 0.584 & 0.397 & $<0.001$ & 0.411 \\
\hline \multicolumn{13}{|l|}{ Texture } \\
\hline Elastic & 4.7 & 4.1 & 3.3 & 3.5 & 3.4 & 3.8 & 3.2 & 3.0 & 0.736 & $<0.0001$ & $<0.0001$ & 0.050 \\
\hline Microstructure & 3.4 & 3.5 & 4.2 & 4.3 & 4.0 & 4.1 & 4.4 & 4.4 & 0.524 & $<0.0001$ & 0.001 & 0.051 \\
\hline
\end{tabular}

${ }^{1}$ All $P$-values for the assessor are $<0.001$. All $P$-values for the interactions milking $\times$ breed, milking $\times$ age, and milking $\times$ breed $\times$ age are $>0.05$, except milking $\times$ breed for grass aroma $(P=0.019)$ and milking $\times$ breed $\times$ age for elastic texture $(P=0.011)$.

the cheese sensory properties, only pepper odor scored lower for the ODM cheese than the TDM cheese $(-0.23$, $P<0.05$; Table 3 ). We did not find evidence of any other significant milking frequency-specific effect on cheese characteristics except for color, being yellower in ODM than in TDM cheese (Table 2). This latter result has never been reported previously but it is probably linked to a higher $\beta$-carotene content of ODM milks and cheese. Indeed, $\beta$-carotene is the main pigment responsible for the yellow coloration of cattle dairy products, and when dietary supplies are similar, as they were in this study, milk $\beta$-carotene content and yellow coloration increase as milk yield decreases because of a concentration effect (Nozière et al., 2006). The quasiabsence of differences in the sensory properties of ODM and TDM cheese is quite surprising when we consider the important milking frequency-specific effect on milk chemical composition. Nevertheless, this finding is in full agreement with the conclusions of O'Brien et al. (2002), who stated that ODM had no adverse effect on milk processability even if those authors did not study cheese sensory properties. The absence of effect of milking frequency on the cheese sensory properties is also consistent with the similarity in gross chemical composition between ODM- and TDM-derived cheeses, as previously observed by other authors comparing 3-times-daily versus twice-daily milkings (Sapru et al., 1997).

\section{CONCLUSIONS}

Based on the results of this study, we conclude that ODM causes important changes in milk composition but does not have an adverse effect on the resulting cheese's sensory properties. Once-daily milking has nevertheless been banned from the production specifications of some European Protected Denomination of Origin cheeses. Our conclusion, however, is based on 2 key conditions: 1) ODM did not increase milk SCC, and 2) the cheese model chosen for this study is an 
uncooked cheese that is not as sensitive to milk plasmin and plasminogen modifications as cooked cheeses such as Swiss-type cheeses.

\section{ACKNOWLEDGMENTS}

We are grateful to S. Hulin from the Comité Interprofessionnel des Fromages du Cantal (Aurillac, France) for the cheese sensory analyses, R. Lavigne from the Unité de Recherches Fromagères (INRA, Aurillac, France) for making the cheeses, and A. Robiquet from the Unité de Recherches sur les Herbivores (INRA, Theix, France) for technical assistance on the sampling and analyses.

\section{REFERENCES}

Ardö, Y. 1999. Evaluating proteolysis by analysing the N content of cheese fractions. Bull. Int. Dairy Fed. 337:4-9.

Auldist, M. J., and C. G. Prosser. 1998. Differential effect of shortterm once-a-day milking on milk yield, milk composition and concentration of secreted blood metabolites in cows with high or low pasture intake. Proc. N.Z. Soc. Anim. Prod. 58:41-43.

Bastian, E. D., and R. J. Brown. 1996. Plasmin in milk and dairy products: An update. Int. Dairy J. 6:435-457.

Chilliard, Y., and G. Lamberet. 1984. La lipolyse dans le lait: Les différents types, mécanismes, facteurs de variation, signification pratique. Lait 64:544-578.

Claesson, O., A. Hansson, N. Gustafsson, and E. Brännäng. 1959. Studies on monozygous cattle twins. XVII. Once-a-day milking compared with twice-a-day milking. Acta Agric. Scand. 8:38-58.

Coulon, J. B., A. Delacroix-Buchet, B. Martin, and A. Pirisi. 2004. Relationships between ruminant management and sensory characteristics of cheeses: A review. Lait 84:221-241.

Coulon, J. B., C. Hurtaud, B. Rémond, and R. Verite. 1998. Factors contributing to variation in the proportion of casein in cows' milk true protein: A review of recent INRA experiments. J. Dairy Res. 65:375-387.

Davis, S. R., V. C. Farr, and K. Stelwagen. 1999. Regulation of yield loss and milk composition during once-daily milking: A review. Livest. Prod. Sci. 59:77-94.

Fox, P. F., J. Law, P. L. H. McSweeney, and J. Wallace. 1999 Biochemistry of cheese ripening. Pages 389-438 in Cheese: Chemistry, Physics and Microbiology. Vol. 1, General Aspects. 2nd ed. P. F. Fox, ed. Aspen Publishers Inc., Gaithersburg, MD.

Grappin, R., T. C. Rank, and N. F. Olson. 1985. Primary proteolysis of proteins during ripening: A review. J. Dairy Sci. 68:531-540.

Jellema, A. 1991. Determination of free fatty acids in milk and milk products. Bull. Int. Dairy Fed., no. 265. Int. Dairy Fed., Brussels, Belgium.

Kelly, A. L., S. Reid, P. Joyce, W. Meaney, and J. Foley. 1998. Effect of decreased milking frequency of cows in late lactation on milk somatic cell count, polymorphonuclear leukocyte numbers, composition and proteolytic activity. J. Dairy Res. 65:365-373.

Lacy-Hulbert, S. J., M. W. Woolford, G. D. Nicholas, C. G. Prosser, and K. Stelwagen. 1999. Effect of milking frequency and pasture intake on milk yield and composition of late lactation cows. J. Dairy Sci. 82:1232-1239.

Lucey, J. A., and P. F. Fox. 1993. Importance of calcium and phosphate in cheese manufacture: A review. J. Dairy Sci. 76:1714-1724.
Macheboeuf, D., J. B. Coulon, and P. D'Hour. 1993. Effect of breed, protein genetic variants and feeding on cows' milk coagulation properties. J. Dairy Res. 60:43-54.

Martin, B., and J. B. Coulon. 1995. Milk production and cheese characteristics. I. Influence of milk production conditions on coagulability of bulk milk. Lait 75:61-80.

Martin, B., P. Pradel, and I. Verdier-Metz. 2000. Effet de la race (Holstein/Montbéliarde) sur les caractéristiques chimiques et sensorielles des fromages. Page 317 in Proc. 7e Rencontres autour des Recherches sur les Ruminants, Paris, France.

McMahon, D. J., and R. J. Brown. 1982. Evaluation of formagraph for comparing rennet solutions. J. Dairy Sci. 65:1639-1642.

Nozière, P., B. Graulet, A. Lucas, B. Martin, P. Grolier, and M. Doreau. 2006. Carotenoids for ruminants: From forages to dairy products. Anim. Feed Sci. Technol. 131:418-450.

O'Brien, B., G. Ryan, W. J. Meaney, D. McDonagh, and A. Kelly. 2002. Effect of frequency of milking on yield, composition and processing quality of milk. J. Dairy Res. 69:367-374.

Pomiès, D., B. Martin, Y. Chilliard, P. Pradel, and B. Rémond. 2007. Once-a-day milking of Holstein and Montbéliarde cows for $7 \mathrm{wk}$ in mid-lactation. Animal 1:1497-1505.

Pomiès, D., B. Rémond, and P. Pradel. 2004. Performances des vaches laitières et qualité du lait lors de la monotraite et après retour à 2 traites par jour, en fonction de la durée de cette pratique et du stade de lactation des animaux. Pages 225-228 in Proc. of the 11e Rencontres autour des Recherches sur les Ruminants, Paris, France.

Rémond, B., and D. Pomiès. 2005. Once-daily milking of dairy cows: A review of recent French experiments. Anim. Res. 54:427-442.

Richardson, B. C. 1983. Variation of the concentration of plasmin and plasminogen in bovine milk with lactation. N.Z. J. Dairy Sci. Technol. 18:247-252.

Rowland, S. J. 1938. The determination of the nitrogen distribution in milk. J. Dairy Res. 9:42-46.

Sapru, A., D. M. Barbano, J. J. Yun, L. R. Klei, P. A. Oltencu, and D. K. Bandler. 1997. Cheddar cheese: Influence of milking frequency and stage of lactation on composition and yield. J. Dairy Sci. $80: 437-446$.

Schaar, J. 1985. Plasmin activity and proteose-peptone content of individual milks. J. Dairy Res. 52:369-378.

Stelwagen, K., S. R. Davis, V. C. Farr, C. G. Prosser, and R. A. Sherlock. 1994. Mammary epithelial cell tight junction integrity and mammary blood flow during an extended milking interval in goats. J. Dairy Sci. 77:426-432.

Stelwagen, K., V. C. Farr, H. A. McFadden, C. G. Prosser, and S. R. Davis. 1997. Time course of milk accumulation-induced opening of mammary tight junctions, and blood clearance of milk components. Am. J. Physiol. 273:379-386.

Verdier, I., J. B. Coulon, P. Pradel, and J. L. Berdagué. 1995. Effect of forage type and cow breed on the characteristics of matured SaintNectaire cheeses. Lait 75:523-533.

Verdier-Metz, I., J. B. Coulon, and P. Pradel. 2001. Relationship between milk fat and protein contents and cheese yield. Anim. Res. 50:365-371.

Verdier-Metz, I., J. B. Coulon, P. Pradel, C. Viallon, H. Albouy, and J. L. Berdagué. 2000. Effect of the botanical composition of hay and casein genetic variants on the chemical and sensory characteristics of ripened Saint-Nectaire type cheeses. Lait 80:361-370.

Verdier-Metz, I., J. B. Coulon, P. Pradel, C. Viallon, and J. L. Berdague. 1998. Effect of forage conservation (hay or silage) and cow breed on the coagulation properties of milks and on the characteristics of ripened cheeses. J. Dairy Res. 65:9-21. 